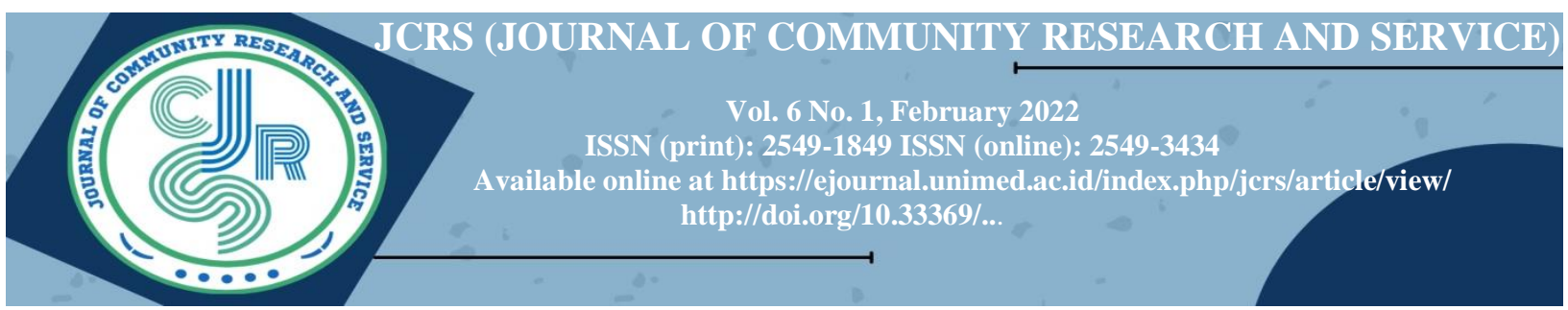

\title{
Pengaruh Kepemimpinan, Karakteristik Pekerjaan dan Kemampuan Kerja Terhadap Kinerja Karyawan PT Petrokimia Gresik
}

\author{
Eli Delvi Yanti \\ Manajemen, Universitas Pembangunan Panca Budi, MEDAN \\ elidelviy@gmail.com
}

\begin{abstract}
The purpose of this study was to analyze the influence of leadership, job characteristics and work ability on the performance of employees of PT Petrokimia Gresik Medan. The data collected in this study were primary data and secondary data, which were collected through data collection instruments in the form of questionnaires, interviews and documentation studies. The sample in this study were 45 respondents. This study uses quantitative data, with multiple linear regression method. The test results show that partially the leadership variable has a positive and significant effect on employee performance. Job characteristics variables have a positive and significant effect on employee performance. The work ability variable has a positive and significant effect on employee performance. Meanwhile, simultaneously, the variables of leadership, job characteristics and work ability have a positive and significant effect on company performance.
\end{abstract}

Keywords: Employee Performance, Leadership, Job Characteristics and Workability

Article history: Received:15-12-2021; Revised: 20-12-2021; Accepted: 17-02-2022; Available online: 26-02-2022 How to cite this article: Yanti, E. D. (2022) Pengaruh Kepemimpinan, Karakteristik Pekerjaan dan Kemampuan Kerja Terhadap Kinerja Karyawan PT Petrokimia Gresik. Journal of Community Research and Service,6(1), xxx$\mathrm{xxx}$.

https://doi.org/10.14710/jcrs.X.X.XXX-XxX

\section{Introduction}

Dalam sebuah organisasi atau instansi, baik instansi pemerintah juga swasta, asal daya insan memiliki peranan yg sangat penting. Bahkan bisa dikatakan bahwa insan adalah kekuatan sentral yg menggerakkan dinamika pada sebuah organisasi, lantaran insan adalah faktor penentu ke arah tercapainya tujuan organisasi secara efektif \& efisien. Para karyawan adalah penggerak segala kegiatan yg terdapat \& terjadi pada sebuah organisasi. Sebuah tempat kerja menjadi suatu organisasi maka karyawanlah yg memegang posisi sentral lantaran tanpa adanya karyawan yg bisa diandalkan \& memiliki loyalitas yg tinggi terhadap jalannya roda organisasi, maka pasti tujuan-tujuan organisasi yg terdapat nir bisa tercapai menggunakan baik. Oleh karenanya demi tercapainya tujuan-tujuan organisasi maka perlu dipelihara \& dikembangkan kinerja karyawan. Kinerja asal menurut istilah job performance atau actual performance yg berarti prestasi kerja atau prestasi sesungguhnya yg dicapai sang seseorang. Pengertian kinerja (prestasi kerja) merupakan output kerja secara kualitas \& kuantitas yg dicapai sang seseorang pegawai pada melaksanakan manfaatnya sinkron menggunakan tanggung jawab yg diberikan kepadanya. [2] Kinerja adalah output kerja \& konduite kerja yg sudah dicapai pada menuntaskan tugas-tugas \& tanggung jawab yg diberikan pada suatu periode tertentu. Sedangkan berdasarkan Mathis \& Jackson pada [3] menjelaskan Kinerja dalam dasarnya merupakan apa yg dilakukan atau nir dilakukan pegawai. Manajemen kinerja merupakan holistik aktivitas yg dilakukan buat menaikkan kinerja perusahaan atau organisasi, termasuk kinerja masing-masing individu \& grup kerja pada perusahaan tersebut.

Berkenaan dengan hal tersebut di atas, banyak faktor yang dapat mempengaruhi kinerja karyawan, beberapa di antaranya berasal dari faktor internal atau eksternal, beberapa faktor yang dianggap penting 
adalah faktor kepemimpinan, karakteristik pekerjaan, dan keterampilan kerja. kemajuan bisnis. Gaya Kepemimpinan seorang pemimpin sangat diperlukan dalam suatu organisasi karena kemajuan suatu organisasi tergantung pada kemampuan pemimpin dalam menjalankan perannya, sehingga organisasi tersebut hidup dan berkembang. Untuk itu seorang pemimpin harus benar-benar memperhatikan gaya kepemimpinannya dalam proses mempengaruhi, mengarahkan kegiatan anggota kelompoknya, dan mengkoordinasikan tujuan anggota dan tujuan organisasi, sehingga keduanya dapat tercapai dalam kinerja seorang pegawai. [1] Orang dengan kekuatan memberi misi memiliki kemampuan untuk membujuk atau mempengaruhi orang lain melalui pola hubungan yang baik guna mencapai tujuan yang telah ditentukan.

Karakteristik individu menjadi keliru satu faktor internal yg sebagai pertimbangan karyawan buat bisa bekerja menggunakan nyaman \& baik. Hal ini dikarenakan meliputi kepribadian, persepsi \& perilaku dan kemampuan eksklusif yg dibawa karyawan ke pada pekerjaan. Atas dasar tadi bisa dikemukakan bahwa semakin karyawan mempunyai kepribadian, perilaku, \& persepsi yg profesional, maka akan menaruh konduite positif bagi karyawan yg bisa berdampak dalam peningkatan kinerja. Faktor ciri pekerjaan adalah faktor eksternal yg bisa berdampak dalam pencapaian kinerja karyawan. Kondisi ini bisa dijelaskan sebagaimana pendapat [5] Pekerjaan dalam dasarnya merupakan sekelompok posisi yg relatif serupa pada hal elemen-elemen pekerjaannya, tugas-tugas \& tanggung jawab-tanggung jawab yg dicakup sang pelukisan pekerjaan yg sama. Atas dasar tadi bisa dikemukakan bahwa semakin karyawan mempunyai cita-cita bertenaga buat berkembang menggunakan mempunyai rasa tanggungjawab yg tinggi, mempunyai variasi tugas \& beban kerja yg sinkron maka akan menaruh konduite positif bagi karyawan yg bisa berdampak dalam peningkatan kinerja.

Kemampuan kerja karyawan merupakan keahlian yang dimiliki karyawan dalam mengerjakan pekerjaannya. Apabila karyawan mendapatkan kesempatan untuk mengembangkan bakat yang dimiliki, serta menggunakannya secara tepat akan berpengaruh pada perkembangan perusahaan. Selain itu dengan kemampuan yang memadai akan dapat membantu karyawan dalam melaksanakan pekerjaan sekarang dan pekerjaan yang akan datang.

Persaingan yang ketat akan mendorong perusahaan untuk meningkatkan kemampuan karyawan, agar produk yang dihasilkan bisa bersaingan di pasaran. Selain itu perusahaan perlu mengetahui dan memenuhi kebutuhan setiap karyawannya, sehingga karyawan bisa bekerja dengan maksimal. Pemenuhan kebutuhan ini sebagai upaya untuk memotivasi karyawan agar lebih giat dan aktif dalam bekerja. Pengertian mampu menurut [9] kemampuan merupakan salah satu unsur dalam kematangan berkaitan dengan pengetahuan atau keterampilan yang dapat diperoleh dari pendidikan, pelatihan dan suatu pengalaman

Fenomena ini terjadi pada PT Petrokimia Gresik, dimana kinerja karyawan pada perusahaan tersebut perlu untuk ditingkatkan. Hasil survey yang dilakukan terjadi penurunan target penjualan yang diakibatkan tidak maksimalnya kinerja pada karyawan tersebut, dan ini dianggap perlu untuk dilakukan penelitian lebih lanjut agar perusahaan dapat berjalan dengan stabil serta memiliki masa depan yang baik

\section{Method}

\section{a. Jenis dan Sifat Penelitian}

Bentuk penelitian ini mencoba menguji gagasan dan mengkonstruksi fakta; mengungkapkan hubungan antar variabel; menawarkan deskripsi statistik; menggambar dan mengantisipasi temuan dengan tujuan menentukan pengaruh satu variabel terhadap variabel lainnya [6].

\section{b. Lokasi Penelitian}

Penelitian ini dilakukan pada PT Petrokimia Gresik Jl. Glugur No. 31-32, Petisah Tengah, Kecamatan Medan Petisah Kota Medan-Sumatera Utara, 20111.

\section{c. Populasi dan Sampel}

Populasi dan sampel pada penelitian ini adalah seluruh karyawan tetap di PT Petrokimia Gresik Medan, yang berjumlah 45 responden.

\section{d. Metode Pengumpulan Data}

\section{1) Kuesioner}

Pengumpulan data sangat bergantung pada penggunaan kuesioner. Kuesioner adalah metode pengumpulan data di mana serangkaian pertanyaan atau pernyataan tersedia untuk peserta survei. Ada banyak pertanyaan tentang subjek yang akan diungkapkan dalam survei, yang didasarkan pada skala model Likert. Penggunaan yang paling umum dari skala ini adalah untuk mengukur perasaan dan pikiran responden tentang objek tertentu. 
2) Wawancara

Memperoleh data yang lebih tepat dan lengkap dengan mewawancarai lebih banyak orang.

3) Dokumentasi.

Peneliti menggunakan dokumentasi, strategi non-interaksi, untuk memperkuat data yang mereka kumpulkan. Untuk mengumpulkan informasi ini, seseorang harus melihat melalui dokumentasi perusahaan.

\section{e. Sumber Data}

1) Data primer

Kata "data primer" mengacu pada informasi yang dikumpulkan langsung dari sumber aslinya. Menurut jenis informasi yang dibutuhkan, jika menyangkut subyek manusia dapat dikumpulkan baik dengan menyiapkan alat atau dengan mengamati secara langsung subyek yang diperiksa.

2) Data Sekunder

Data sekunder mencakup informasi yang diperoleh dari berbagai publikasi, seperti buku, jurnal, dan karya ilmiah lainnya, yang semuanya relevan dengan topik yang sedang dibahas.

\section{f. Teknik Analisis Data}

1) Analisis Statistik Deskriptif

Untuk sebagian besar, statistik deskriptif digunakan untuk memberikan wawasan tentang variabel penelitian studi. Ini adalah metode analisis deskriptif di mana data dikumpulkan untuk memberikan informasi dan pandangan keseluruhan dari materi pelajaran yang sedang dibahas. Menganalisis data dengan menggunakan statistik deskriptif memungkinkan peneliti untuk mendapatkan gambaran yang luas dari fenomena yang mereka pelajari.

2) Analisis Regresi Linear Berganda

Untuk menguji hubungan linier antara tiga atau lebih variabel bebas dan satu (satu) variabel terikat, analisis regresi berganda adalah metode analisis data pilihan. Penelitian ini menggunakan model regresi sebagai berikut:

$$
Y=\alpha+X 1+X 2+X 3+\varepsilon
$$

\section{3) Pengujian Hipotesis}

Uji F (uji koefisien regresi simultan) atau uji koefisien regresi individual (parsial) digunakan untuk menguji pengaruh faktor independen terhadap variabel dependen (uji t).

4) Uji Asumsi Klasik

Persamaan regresi dapat diuji keakuratannya dengan menggunakan uji asumsi, yang mencoba menetapkan bahwa persamaan regresi yang diturunkan tidak bias dan konsisten [8]. Jika terjadi heteroskedastisitas atau multikolinearitas, varians tidak akan konstan, dan signifikansi koefisien regresi akan lebih rendah. [7] Uji asumsi klasik meliputi uji normalitas, multikolinearitas, dan heteroskedastisitas. Jika varians tidak konstan, kesalahan standar akan lebih tinggi. Uji asumsi klasik harus dilakukan sebagai hasilnya.

\section{Findings and Discussion}

Tabel 1. Analisis Statistik Deskriptif. Descriptive Statistics

\begin{tabular}{|c|c|c|c|c|c|c|c|}
\hline & \multirow{2}{*}{$\begin{array}{c}\mathrm{N} \\
\text { Statistic }\end{array}$} & \multirow{2}{*}{$\begin{array}{c}\text { Minimum } \\
\text { Statistic }\end{array}$} & \multirow{2}{*}{$\begin{array}{c}\text { Maximum } \\
\text { Statistic } \\
\end{array}$} & \multirow{2}{*}{$\begin{array}{c}\text { Sum } \\
\text { Statistic }\end{array}$} & \multicolumn{2}{|c|}{ Mean } & \multirow{2}{*}{$\begin{array}{c}\text { Std. } \\
\text { Deviation } \\
\text { Statistic } \\
\end{array}$} \\
\hline & & & & & Statistic & Std. Error & \\
\hline Kepemimpinan & 45 & 13.00 & 29.00 & 944.00 & 20.9778 & .68127 & 4.57010 \\
\hline Karakteristik Pekerjaan & 45 & 7.00 & 25.00 & 701.00 & 15.5778 & .70316 & 4.71694 \\
\hline Kemampuan Kerja & 45 & 8.00 & 20.00 & 591.00 & 13.1333 & .47418 & 3.18091 \\
\hline Kinerja Karyawan & 45 & 16.00 & 35.00 & 1124.00 & 24.9778 & .69521 & 4.66364 \\
\hline Valid N (listwise) & 45 & & & & & & \\
\hline
\end{tabular}

Sumber: Data Primer diolah dengan SPSS v.25, 2022 
Untuk setiap variabel yang valid, ada total 45 titik data, seperti yang ditunjukkan pada Tabel 1. Nilai minimum dan maksimum untuk variabel kinerja karyawan $(\mathrm{Y})$ berkisar dari $\$ 16$ hingga $\$ 35,00$; rataratanya adalah $\$ 24,9778$, dan simpangan bakunya adalah 4,66364 , menunjukkan bahwa nilai rata-rata lebih tinggi dari nilai standar dan bahwa simpangan datanya rendah, menunjukkan distribusi nilai yang merata. Untuk variabel kepemimpinan (X1) nilai terendah dan tertinggi berturut-turut adalah 13,00 dan 29,00 dengan nilai mean 20,9778 dan standar deviasi 4,57010 yang berarti nilai mean lebih besar dari nilai standar, dan sebaran nilai didistribusikan secara merata. Seperti yang Anda lihat, ada sedikit perbedaan antara mean dan standar deviasi untuk variabel karakteristik pekerjaan (X2): mean adalah 15,5778 poin, dan standar deviasinya, sebesar 4,71694, menunjukkan bahwa nilai mean berada di atas standar deviasi, menunjukkan bahwa penyebaran data adalah seragam. Dengan kata lain, karena mean (X3) lebih tinggi dari standar deviasi $(3,1891)$, standar deviasi data rendah dan distribusi nilai seragam, variabel workability (X3) memiliki nilai rata-rata 13,1333.

Tabel 2. Analisis Regresi Linear Berganda.

Coefficients $^{\mathrm{a}}$

\begin{tabular}{|c|c|c|c|c|c|c|c|c|}
\hline & & \multicolumn{2}{|c|}{$\begin{array}{l}\text { Unstandardized } \\
\text { Coefficients }\end{array}$} & \multirow{2}{*}{$\begin{array}{c}\text { Standardized } \\
\text { Coefficients }\end{array}$} & \multirow[b]{2}{*}{$\mathrm{t}$} & \multirow[b]{2}{*}{ Sig. } & \multicolumn{2}{|c|}{$\begin{array}{l}\text { Collinearity } \\
\text { Statistics }\end{array}$} \\
\hline \multicolumn{2}{|c|}{ Model } & $\mathrm{B}$ & Std. Error & & & & Tolerance & VIF \\
\hline \multirow[t]{4}{*}{1} & (Constant) & 0.193 & 0.456 & & 423 & .675 & & \\
\hline & Kepemimpinan (X1) & 0.303 & 0.092 & 0.331 & 3.292 & .002 & 0.931 & 1.074 \\
\hline & $\begin{array}{l}\text { Karakteristik } \\
\text { Pekerjaan (X2) }\end{array}$ & 0.278 & 0.090 & 0.315 & 3.083 & .004 & 0.903 & 1.108 \\
\hline & $\begin{array}{l}\text { Kemampuan Bekerja } \\
\text { (X3) }\end{array}$ & 0.397 & 0.083 & 0.483 & 4.808 & .000 & 0.935 & 1.069 \\
\hline
\end{tabular}

a. Dependent Variable: Kinerja Karyawan (Y)

Sumber: Data Primer diolah dengan SPSS v.25, 2022

Berdasarkan Tabel 2, hasil uji regresi linear berganda terdapat dikolom koefisien regresi. Standart persamaan regresi linear berganda dapat diperoleh hasil, sebagai berikut:

$$
Y=0,193+0,303 X 1+0,278 X 2+0,397 X 3+e
$$

Nilai 0,193 dikenal sebagai konstanta. Jika kepemimpinan, kualitas kerja, dan kemampuan kerja tidak berpengaruh terhadap variabel dependen kinerja karyawan, maka nilai variabel dependennya adalah 0,193. Variabel kepemimpinan memiliki nilai koefisien regresi positif sebesar 0,303. Akibatnya, ketika kepemimpinan dinaikkan satu satuan, kinerja pegawai cenderung naik 0,303 persen. Variabel karakteristik kerja memiliki nilai koefisien regresi positif sebesar 0,278 yang sudah diketahui dengan baik. Kinerja pegawai cenderung naik sebesar 0,278 unit untuk setiap kenaikan satu unit karakteristik kerja. Analisis regresi menunjukkan bahwa variabel kemampuan kerja memiliki nilai koefisien positif sebesar 0,397. Hal ini menunjukkan bahwa untuk setiap satu unit keuntungan dalam produktivitas, ada kenaikan 0,397 unit dalam kinerja karyawan.

Tabel 3. Hasil Uji t.

Coefficients $^{\mathrm{a}}$

\begin{tabular}{|l|c|c|c|c|c|}
\hline \multirow{2}{*}{ Model } & \multicolumn{2}{|c|}{$\begin{array}{c}\text { Unstandardized } \\
\text { Coefficients }\end{array}$} & $\begin{array}{c}\text { Standardized } \\
\text { Coefficients }\end{array}$ & $\mathrm{t}$ & Sig. \\
\cline { 2 - 6 } & $\mathrm{B}$ & $\begin{array}{c}\text { Std. } \\
\text { Error }\end{array}$ & Beta & & \\
\hline 1 (Constant) & 0.193 & 0.456 & & & \\
Kepemimpinan (X1) & 0.303 & 0.092 & 0.331 & 3.292 & 0.675 \\
Karakteristik Pekerjaan (X2) & 0.278 & 0.090 & 0.315 & 3.083 & 0.002 \\
Kemampuan Kerja (X3) & 0.397 & 0.083 & 0.483 & 4.808 & 0.000 \\
\hline
\end{tabular}

a. Dependent Variable: Kinerja Karyawan

Sumber: Data Primer diolah dengan SPSS v.25, 2022 
Pada Tabel 3 dapat dilihat bahwa nilai thitung variabel Kepemimpinan (X1) (ttabel 3,292 > 1,679) adalah positif dan signifikan yang artinya variabel Kepemimpinan (X1) berpengaruh positif dan signifikan terhadap Kinerja Karyawan variabel (Y) PT Petrokimia Gresik. Karakteristik Pekerjaan (X2) diketahui berpengaruh positif dan signifikan terhadap variabel Kinerja Karyawan (Y) PT Petrokimia Gresik dengan memiliki thitung 3,083 > 1,679 dan sig alpha masing-masing 0,004 0,005. Kinerja karyawan pada PT Petrokimia Gresik dipengaruhi secara positif dan signifikan oleh variabel Workability (X3), yang ditunjukkan dengan nilai thitung sebesar 4,808>1,679 pada ttabel dan sig alpha sebesar 0,000 0,005 .

Tabel 4. Hasil Uji F.

ANOVA $^{\mathrm{a}}$

\begin{tabular}{|l|r|r|r|r|l|}
\hline Model & Sum of Squares & $d f$ & Mean Square & F & Sig. \\
\hline 1 Regression & 6.547 & 3 & 2.182 & 21.676 & $0.000^{\mathrm{b}}$ \\
Residual & 4.128 & 41 & 0.101 & & \\
Total & 10.675 & 44 & & & \\
\hline
\end{tabular}

a. Dependent Variable: Kinerja Karyawan

b. Predictors: (Constant), Kemampuan Kerja, Karakteristik Pekerjaan, Kepemimpinan

Sumber: Data Primer diolah dengan SPSS v.25, 2022

Dapat ditunjukkan dengan melihat Tabel 4 bahwa model persamaan ini memiliki tingkat alpha 0,000, yang lebih kecil dari alpha 0,05 Semua variabel independen, termasuk Kepemimpinan (X1), Karakteristik Pekerjaan (X2), dan Kemampuan Kerja ( X3), berpengaruh signifikan terhadap variabel terikat yaitu Kinerja Karyawan (Y). Tanda tangan alpha 0,000 0,05, sedangkan Fhitung > dari Ftabel yaitu 21,676 > 3,22, menunjukkan bahwa variabel bebas Kepemimpinan (X1), Karakteristik Kerja (X2), dan Kemampuan Kerja berpengaruh positif dan signifikan terhadap variabel terikat Kinerja Karyawan secara simultan (Y ) Produksi PT Bensin di Gresik.

Tabel 5. Hasil Koefisien Determinasi $\left(\mathrm{R}^{2}\right)$.

Model Summary

\begin{tabular}{|c|r|r|r|r|}
\hline Model & $\mathrm{R}$ & R Square & Adjusted $R$ Square & $\begin{array}{c}\text { Std. Error of the } \\
\text { Estimate }\end{array}$ \\
\hline 1 & $0.783^{\mathrm{a}}$ & 0.613 & 0.585 & 0.31731 \\
\hline
\end{tabular}

a. Predictors: (Constant), Kemampuan Kerja, Karakteristik Pekerjaan, Kepemimpinan

Sumber: Data Primer diolah dengan SPSS v.25, 2022

Tabel 5 menunjukkan bahwa R2 (R Squared) sama dengan 0,613 atau 61,3 persen dari total. Kinerja karyawan (Y) di PT Petrokimia Gresik sebesar 61,3 persen dipengaruhi oleh kepemimpinan, karakteristik pekerjaan, dan kemampuan kerja, sedangkan sisanya sebesar 38,7 persen dijelaskan atau dipengaruhi oleh variabel lain yang tidak dibahas dalam penelitian ini, seperti terlihat pada grafik ini.

Tabel 6. Hasil Uji Normalitas.

One-Sample Kolmogorov-Smirnov Test

Unstandardized

Residual

\begin{tabular}{|llr|}
\hline N & & 45 \\
& Mean & 0.0000000 \\
Most Extreme Differences & Std. Deviation & 0.30629975 \\
& Absolute & 0.093 \\
& Positive & 0.093 \\
Test Statistic & Negative & -0.062 \\
Asymp. Sig. (2-tailed) & & 0.621 \\
\hline
\end{tabular}


a. Test distribution is Normal.

b. Calculated from data.

c. Lilliefors Significance Correction.

$d$. This is a lower bound of the true significance.

Sumber: Data Primer diolah dengan SPSS v.25, 2022

Dengan hasil uji Kolmogorov-Smirnov sebesar 0,621, maka dapat dikatakan bahwa semua data berdistribusi normal, seperti terlihat pada Tabel 6. Dengan menggunakan normal probability plot dan histogram, kita dapat menentukan apakah data tersebut berdistribusi kumulatif normal atau tidak dengan membandingkannya dengan data secara keseluruhan. Seperti yang dapat dilihat dari berikut ini, hasil tesnya positif.

\section{Normal P-P Plot of Regression Standardized \\ Residual}

Dependent Variable: Kinerja Karyawan ( $)$

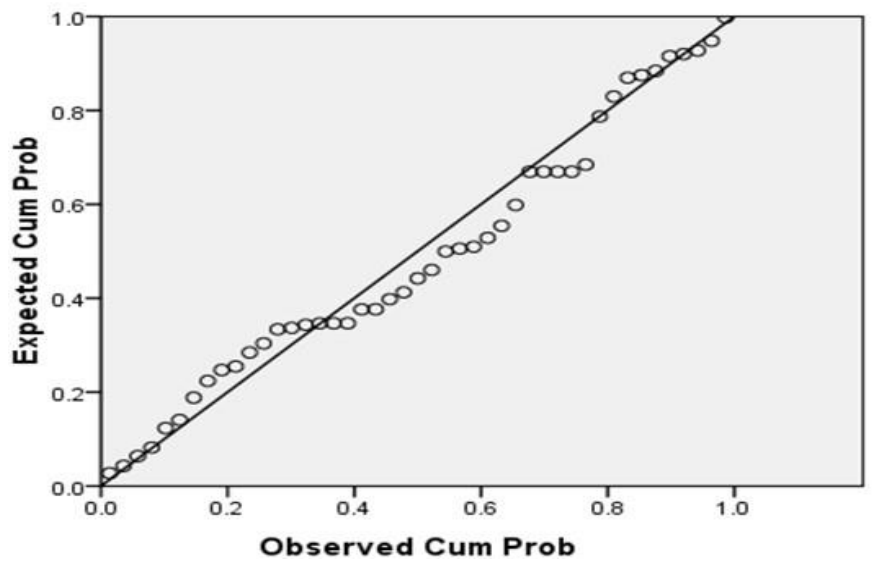

Gambar 1. Normal P-Plot.

Sumber: Data Primer diolah dengan SPSS v.25, 2022

Melihat Gambar 1 menunjukkan distribusi data yang berada dalam pita sempit di sekitar garis diagonal, yang menunjukkan normalitas dan memungkinkan pengujian untuk melanjutkan ke tahap baru.

\section{Histogram}

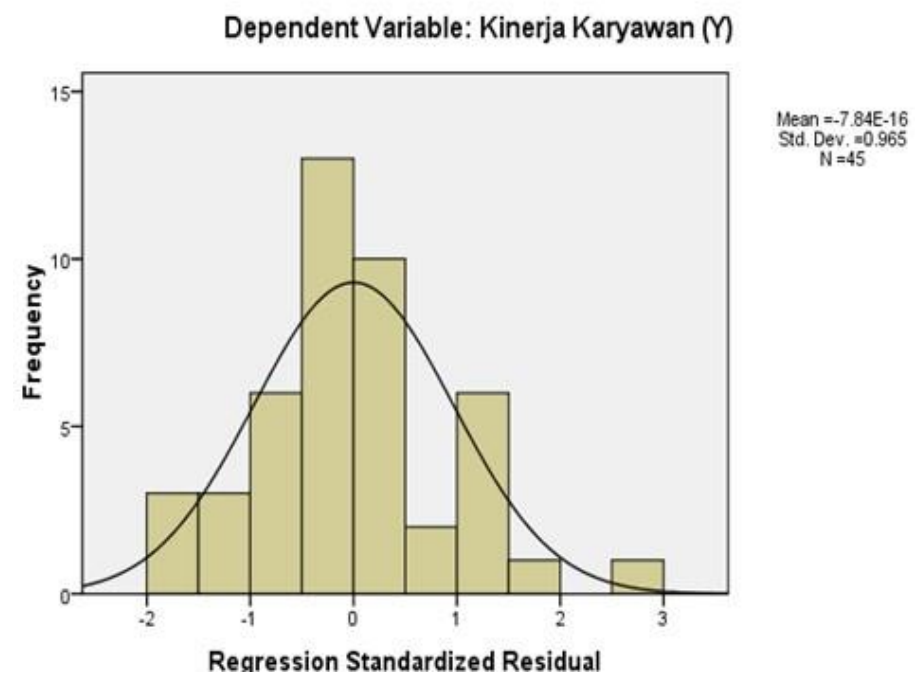

Gambar 2. Histogram.

Sumber: Data Primer diolah dengan SPSS v.25, 2022 
Data dalam penelitian ini diasumsikan berdistribusi normal atau mendekatinya dalam penelitian ini karena histogram berbentuk lonceng yang ditunjukkan pada Gambar 2.

Tabel 7. Hasil Uji Multikolinearitas.

Coefficients $^{\mathrm{a}}$

\begin{tabular}{|c|c|c|c|c|c|c|c|}
\hline \multirow[b]{2}{*}{ Model } & \multicolumn{2}{|c|}{$\begin{array}{l}\text { Unstandardized } \\
\text { Coefficients }\end{array}$} & \multirow[t]{2}{*}{$\begin{array}{l}\text { Standar } \\
\text { dized } \\
\text { Coeffici } \\
\text { ents }\end{array}$} & \multirow[t]{2}{*}{$\mathrm{t}$} & \multirow[t]{2}{*}{$\begin{array}{l}\mathrm{Si} \\
\mathrm{g} .\end{array}$} & \multicolumn{2}{|c|}{$\begin{array}{l}\text { Collinearity } \\
\text { Statistics }\end{array}$} \\
\hline & B & $\begin{array}{l}\text { Std. } \\
\text { Erro } \\
\mathrm{r}\end{array}$ & & & & $\begin{array}{l}\text { Toleranc } \\
\text { e }\end{array}$ & $\begin{array}{l}\text { VI } \\
\text { F }\end{array}$ \\
\hline (Constant) & 0.193 & $\begin{array}{l}0.45 \\
6\end{array}$ & & $\begin{array}{l}0.4 \\
23\end{array}$ & $\begin{array}{l}0 . \\
6 \\
7 \\
5\end{array}$ & & \\
\hline Kepemimpinan (X1) & 0.303 & $\begin{array}{l}0.09 \\
2\end{array}$ & 0.331 & $\begin{array}{l}3.2 \\
92\end{array}$ & $\begin{array}{l}0 . \\
0 \\
0 \\
2\end{array}$ & 0.931 & $\begin{array}{l}1.0 \\
74\end{array}$ \\
\hline $\begin{array}{l}\text { Karakteristik Pekerjaan } \\
\text { (X2) }\end{array}$ & 0.278 & $\begin{array}{l}0.09 \\
0\end{array}$ & 0.315 & $\begin{array}{l}3.0 \\
83\end{array}$ & $\begin{array}{l}0 . \\
0 \\
0 \\
4\end{array}$ & 0.903 & $\begin{array}{l}1.1 \\
08\end{array}$ \\
\hline Kemampuan Kerja (X3) & 0.397 & $\begin{array}{l}0.08 \\
3\end{array}$ & 0.4 .83 & $\begin{array}{l}4.8 \\
08\end{array}$ & $\begin{array}{l}0 . \\
0 \\
0 \\
0\end{array}$ & 0.935 & $\begin{array}{l}1.0 \\
69\end{array}$ \\
\hline
\end{tabular}

a. Dependent Variable: Kinerja Karyawan

Sumber: Data Primer diolah dengan SPSS v.25, 2022

Melihat Tabel 7 menunjukkan bahwa tidak ada variabel independen yang memiliki nilai toleransi lebih dari 0,010, yang menunjukkan bahwa tidak ada korelasi antara variabel independen yang nilainya lebih besar dari 95\%. Nilai Variance Inflation Factor (VIF) juga menunjukkan hal yang sama. sama, yaitu tidak ada variabel bebas yang memiliki nilai VIF kurang dari 10. Akibatnya, model regresi yang digunakan dalam penelitian ini tidak menunjukkan multikolinearitas.

Tabel 8. Hasil Uji Heteroskedastisitas.

Coefficients $^{\mathrm{a}}$

\begin{tabular}{|c|c|c|c|c|c|c|}
\hline \multirow{2}{*}{\multicolumn{2}{|c|}{ Model }} & \multicolumn{2}{|c|}{$\begin{array}{l}\text { Unstandardized } \\
\text { Coefficients }\end{array}$} & \multirow{2}{*}{$\begin{array}{c}\begin{array}{c}\text { Standardize } \\
\mathrm{d} \\
\text { Coefficient } \\
\mathrm{s}\end{array} \\
\text { Beta }\end{array}$} & \multirow[b]{2}{*}{$\mathrm{t}$} & \multirow[b]{2}{*}{ Sig. } \\
\hline & & $\mathrm{B}$ & Std. Error & & & \\
\hline \multirow[t]{4}{*}{1} & (Constant) & .344 & .279 & & 1.232 & .225 \\
\hline & Kepemimpinan (X1) & .002 & .056 & .005 & .033 & .973 \\
\hline & $\begin{array}{l}\text { Karakteristik Pekerjaan } \\
(\mathrm{X} 2)\end{array}$ & .045 & .055 & .131 & .820 & .417 \\
\hline & $\begin{array}{l}\text { Kemampuan Bekerja } \\
\text { (X3) }\end{array}$ & -.076 & .051 & -.236 & 1.504 & .140 \\
\hline
\end{tabular}

a. Dependent Variable: abs_res

Sumber: Data Primer diolah dengan SPSS v.25, 2022

Dari Tabel 8 dapat dilihat bahwa hasil uji heteroskedastisitas menunjukkan bahwa tidak terdapat heteroskedastisitas pada variabel Kepemimpinan (X1), Karakteristik Pekerjaan (X2), dan Kemampuan Kerja (X3) menunjukkan nilai lebih besar dari 0,05 hal ini menunjukkan bahwa terdapat tidak terjadi heteroskedastisitas. 


\section{(1) Pengaruh Kepemimpinan terhadap Kinerja Karyawan}

Berdasarkan analisis data dapat disimpulkan bahwa variabel Kepemimpinan (X1) berpengaruh positif signifikan terhadap variabel Kinerja Karyawan (Y) PT Petrokimia Gresik. Penelitian telah menunjukkan bahwa kinerja karyawan akan meningkat sebagian jika atasan mereka lebih efektif. Para pemimpin di perusahaan-perusahaan ini harus memupuk rasa kerja tim di antara para pekerja mereka. Jika terjadi kesalahan dalam bekerja, karyawan membutuhkan bimbingan dari atasannya agar proyek dapat selesai tepat waktu. Jika pimpinan perusahaan dan karyawan memiliki hubungan kerja yang baik, maka kinerja karyawan perusahaan akan lebih baik. Sangat penting bahwa tujuan perusahaan dipenuhi melalui manajemen sumber daya manusia yang efektif. Gaya kepemimpinan seseorang dapat dilihat sebagai landasan kepemimpinannya, dalam arti mereka menggunakan metode yang mereka sukai untuk melaksanakan tanggung jawab kepemimpinannya (Noor, 2013). Penelitian sebelumnya oleh Ilham Safar (2018) menemukan bahwa kepemimpinan memiliki pengaruh yang signifikan terhadap kinerja karyawan di PT Perkebunan Nusantara XIV Makassar, sejalan dengan temuan penelitian ini. Andarias Kuddy (2017) sebelumnya menemukan bahwa kinerja pegawai Dinas Pertanian dan Ketahanan Pangan Provinsi Papua sangat dipengaruhi oleh tindakan pimpinannya. Penelitian sebelumnya yang dilakukan oleh Djoko Setyo Widodo (2014) menyatakan bahwa kepemimpinan berpengaruh positif dan signifikan terhadap kinerja karyawan Industri Manufaktur di Jawa Barat. Liridon Veliu dkk. (2017) sebelumnya telah menemukan bahwa kepemimpinan berdampak pada kinerja karyawan di perusahaan sektor swasta Kosovo. Dwi Haryanto (2017), sebaliknya, menemukan bahwa gaya kepemimpinan di CV Indryferyto Group Yogyakarta tidak berpengaruh positif atau substansial terhadap kinerja karyawan.

\section{(2) Pengaruh Karakteristik Pekerjaan terhadap Kinerja Karyawan}

Berdasarkan hasil analisis, maka diperoleh kesimpulan bahwa Karakteristik Pekerjaan (X2) berpengaruh positif dan signifikan terhadap variabel Kinerja Karyawan (Y) PT Petrokimia Gresik. Karakteristik pekerjaan merupakan faktor eksternal yang dapat berdampak pada pencapaian kinerja karyawan. Kondisi yang terjadi pada perusahaan masih ada sebagian karyawan yang belum dapat menyelesaikan pekerjaan sesuai tanggung jawab yang diberikan, minimnya inovasi. Hal ini terjadi karena antara pimpinan dan karyawan belum benar-benar menjalin hubungan yang baik sehingga karyawan jarang untuk menyampaikan pendapatnya tentang situasi pekerjaan tersebut. Kondisi ini dapat dijelaskan sebagaimana pendapat [4] yang menyatakan bahwa karakteristik pekerjaan atau job characteristic merupakan sebuah pekerjaan yang dapat melahirkan tiga keadaan psikologis dalam diri seorang karyawan yaitu merasakan makna kerja, memikul tanggung jawab akan hasil kerja, dan pengetahuan akan hasil kerja. Hasil penelitian ini sesuai dengan penelitian terdahulu yang dilakukan oleh Anik Yuliati (2020) dimana hasil menunjukkan bahwasanya karakteristik berpengaruh terhadap kinerja Guru pada SMK Diponegoro Sidoarjo. Penelitian terdahulu yang dilakukan oleh Nur Harti Hamza (2018) dimana hasil penelitian menunjukkan bahwa karakteristik pekerjaan berpengaruh positif dan signifikan terhadap kinerja karyawan pada PT Mahakam Sawit Plantation Site Tanjung Harapan di Tenggarong. Penelitian terdahulu yang dilakukan oleh Sugianto dkk (2018) menunjukkan bahwa karakteristik memiliki pengaruh yang positif terhadap kinerja karyawan Koperasi di Solo Jawa Tengah. Penelitian terdahulu yang dilakukan oleh Sandra Kiffin dan John Cordery (2010) menujukkan hasil bahwanya kerakteristik memiliki pengaruh kuat terhadap prefensi karyawan dalam kerja tim. Sedangkan penelitian terdahulu yang dilakukan oleh Eko Parlindungan dkk. (2018) menyatakan bahwa karakteristik individu berpengaruh positif tetapi tidak signifikan terhadap kinerja karyawan PT PLN (Persero) Rayon Manado Selatan.

\section{(3) Pengaruh Kemampuan Kerja terhadap Kinerja Karyawan}

Berdasarkan hasil analisis, maka diperoleh kesimpulan variabel Kemampuan Kerja (X3) berpengaruh positif dan signifikan terhadap variabel Kinerja Karyawan (Y) PT Petrokimia Gresik. Kemampuan kerja karyawan merupakan keahlian yang dimiliki karyawan dalam mengerjakan pekerjaannya. Apabila karyawan mendapatkan kesempatan untuk mengembangkan bakat yang dimiliki, serta menggunakannya secara tepat akan berpengaruh pada perkembangan perusahaan. Kemampuan pada karyawan perusahaan tersebut dalam menyelesaikan pekerjaan masih belum disesuaikan. Sebagian dari karyawan diberi pekerjaan diluar job description tanpa diberi arahan dalam menyelesaikan pekerjaannya dan mengakibatkan hasil kerja kurang maksimal bahkan sering terjadi kesalahan. Kemampuan, menurut Wojowasito (2010) adalah kesanggupan atau kecakapan, sedangkan kemampuan berarti seseorang yang memiliki kecakapan atau kesanggupan untuk menjalankan sesuatu yang diwujudkan melalui tindakannya untuk meningkatkan produktivitas kerjanya. Hasil penelitian ini sesuai dengan penelitian terdahulu yang 
dilakukan oleh Ersa Prawira Budi, Selfi Budi Helpiastuti dan Hari Wahyudi (2021) dimana hasil penelitian menunjukkan bahwa kemampuan kerja berpengaruh signifikan terhadap kinerja karyawan pada Aparatur Sipil Negara di Dinas Tanaman Holtikultura dan Perkebunan Kab. Situbondo. Penelitian terdahulu yang dilakukan oleh R. Soesetyo Soetadji (2011) dimana hasil penelitian menunjukkan bahwa kepemimpinan, kemampuan kognitif dan Karakteristik berpengaruh signifikan terhadap kinerja karyawan pada Balai Besar POM Yogyakarta. Penelitian terdahulu yang dilakukan oleh Vilzati Juned dkk (2021) menunjukkan bahwa kemampuan kerja berpengaruh terhadap peningkatan kinerja pegawai Bappeda Aceh Jaya. Penelitian terdahulu yang dilakukan oleh Ester Manik dan Iwan Sidharta (2017) menunjukkan bahwa kemampuan berpengaruh signifikan terhadap kinerja karyawan Badan Publik di Bandung Indonesia. Sedangkan penelitian terdahulu yang dilakukan oleh Alan Hidayat dan Hotlan Siagian (2017) menujukkan bahwa kemampuan tidak berpengaruh terhadap kinerja karyawan pada CV Sinar Agung.

\section{(4) Pengaruh Kepemimpinan, Karakteristik Pekerjaan dan Kemampuan Kerja terhadap Kinerja Karyawan}

Berdasarkan hasil analisis, maka diperoleh kesimpulan bahwa secara simultan variabel bebas yaitu Kepemimpinan (X1), Karakteristik Pekerjaan (X2) dan Kemampuan Kerja (X3) berpengaruh signifikan terhadap variabel terikat Kinerja Karyawan (Y) PT Petrokimia Gresik. Pada dasarnya kinerja (prestasi kerja) adalah hasil kerja secara kualitas dan kuantitas yang dicapai oleh seorang pegawai dalam melaksanakan fungsinya sesuai dengan tanggung jawab yang diberikan kepadanya. Berdasarkan uraian tersebut untuk dapat mencapai suatu tujuan organisasi maka harus memenuhi hasil kerja yang baik untuk meningkakan kinerja karyawan. Menurut Simamora (2012) kinerja adalah aktivitas yang berkaitan dengan unsur-unsur yang terlibat dalam proses untuk menghasilkan sesuatu output.

\section{Conclusion}

a. Hasil dari pengujian statistik uji $\mathrm{F}$ menunjukkan bahwa kepemimpinan, karakteristik pekerjaan dan kemampuan kerja secara bersama-sama berpengaruh posistif dan signifikan terhadap kinerja karyawan PT Petrokimia Gresik.

b. Hasil dari pengujian statistik uji t menunjukkan secara individual (parsial) kepemimpinan berpengaruh positif dan signifikan terhadap kinerja karyawan PT Petrokimia Gresik.

c. Hasil dari pengujian statistik uji t menunjukkan secara individual (parsial) karakteristik pekerjaan berpengaruh positif dan signifikan terhadap kinerja karyawan PT Petrokimia Gresik.

d. Hasil dari pengujian statistik uji t menunjukkan secara individual (parsial) kemampuan kerja berpengaruh posistif dan signifikan terhadap kinerja karyawan PT Petrokimia Gresik.

e. Berdasarkan koefisien determinasi (R2) diperoleh bahwa $61.8 \%$ kinerja karyawan dipengaruhi sangat erat oleh kepemimpinan, karakteristik pekerjaan dan kemampuan kerja, sedangkan $38.2 \%$ lagi sisanya dijelaskan oleh faktor lain yang tidak dimasukkan dalam variabel penelitian ini.

\section{References}

[1] Amirullah. (2015). Pengantar Manajemen. Jakarta: Mitra Wacana Media.

[2] Kasmir. (2016). Manajemen Sumber Daya Manusia (Teori dan Praktik). Depok: PT Rajagrafindo Persada

[3] Masram, (2017). Manajemen Sumber Daya Profesional. Sidoarjo: Zifatama Publisher.

[4] Munandar, Haris, Sitanggang, Sally. (2011). Mengenal HAKI-Hak Kekayaan Intelektual, Jakarta: Erlangga.

[5] Simamora, Henry (2015). Manajemen Sumber Daya Manusia. Yogyakarta: STIEY

[6] Sugiyono. (2011). Metode Penelitian Administratif. Bandung: Alfabeta.

[7] __ (2012). Memahami Penelitian Kualitatif. Bandung: Alfabeta.

[8] Santoso, Singgih. (2012). Panduan Lengkap SPSS Versi 20. Jakarta: PT Elex Media Komputindo.

[9] Thoha, Miftah. (2013). Kepemimpinan dalam manajemen. Jakarta: Raja Grafindo Persada. 